\title{
Genetic Diversity and Relationship of Indonesian Indigenous Chickens Inferred from Microsatellite DNA Markers
}

\author{
H. Ashari ${ }^{*}$, S. Sulandari, M.S.A. Zein and J.L. Han ${ }^{1}$ \\ Department of Zoology, Research Center for Biology \\ The Indonesian Institute of Sciences (LIPI) \\ Cibinong, Bogor,Indonesia
}

\begin{abstract}
A total of 1178 individuals of nearly complete sampling of 49 populations belong to 14 most popular Indonesian indigenous chicken breeds, geographically localized in different islands, were genotyped using 20 microsatellite DNA markers to investigate their molecular diversity and genetic relationship. In total, 259 alleles were observed among 49 populations of Indonesian indigenous chickens across 20 loci. The mean number of alleles (MNA) per locus ranged from 4.20 to 7.60. The observed $\left(H_{O}\right)$ and expected heterozygosity $\left(H_{E}\right)$ values averaged over loci varied from 0.50 to 0.67 and from 0.55 to 0.72 , respectively, and they displayed a similar distribution pattern to that observed for MNA across the populations. The results indicated that there was rich and unique genetic diversity among most of the populations. The presence of significantly positive $F_{I S}$ values $(P<0.05)$, suggested the occurrence of inbreeding within most of these populations, leading to partition genetic diversity among the major islands. Some localized chicken populations have developed a distinct genetic background due to historical trading and long term geographic isolation. On the other hand, a few populations kept in urban areas may have been genetically introgressed with commercial chicken breeds/lines to some extent, forming different genetic structure. These findings will serve as scientific basis for the development of rational policies to sustainably conserve and utilize these unique Indonesian indigenous chicken genetic resources.
\end{abstract}

Keywords: Genetic diversity, Indonesian indigenous chicken, microsatellite marker, relationship

\section{INTRODUCTION}

Indonesian Archipelago, comprising thousands of islands from Sumatra in the west to New Guinea in the east, has been recognized as one of the areas of mega-biodiversity. Indigenous chickens in Indonesia have played an important role in poultry production of the country (Sartika, 2007). Chickens are the most acceptable form of protein among Indonesians as there are few religious or social taboos associated with them compared to other livestock species such as pig and cattle.

Scientists who involved in investigating the process of chicken domestication, have shown different opinions about Red Jungle-fowl (Gallus gallus) as the ancestor of today's domestic chicken (Lindqvist et al., 2002; Väisänen and Jensen, 2003, 2004; Weeks and Nicol, 2006).

1 CAAS-ILRI Joint Laboratory on Livestock and Forage Genetic Resources, Institute of Animal Science, Chinese Academy of Agricultural Sciences (CAAS), Beijing 100193, China

Corresponding author: numenius.phaeopus@gmail.com 
Although the study on relationship and evolutionary similarities between Red Jungle-fowls and different chicken populations shed light on this matter (Moiseyeva et al., 2003), there are still some debates on whether the origin of domesticated chicken was monophyletic or polyphyletic (Crawford, 1990). However, recent studies suggested Red Jungle-fowl to be the direct ancestor of all domesticated chickens (Moreng and Avens, 1985; Crawford, 1990; Sullivan, 1991; Siegel et al., 1992; Fumihito et al., 1994, 1996; Romanov and Weigend, 2001; Hillel et al., 2003; Väisänen et al., 2005).

Indonesia has various descript and non-descript breeds of indigenous chickens which are popular among Indonesian communities. Nataamijaya (2000) suggested that there are 31 breeds of Indonesian indigenous chicken breeds, of which the most popular ones are: Pelung, Black Kedu, White Kedu, Kapas, Cemani, Arab, Merawang, Kate, Gaok, Sentul, Wareng, Nunukan, Tolaki, Tukong, Ayuni, and Jantur. Study on genetic variation of Indonesian indigenous chickens is expected to provide scientific basis for the development of a breeding program for them to match the improved genotypes under with low-input backyard production system (Sulandari et al., 2007). This study was conducted to examine the genetic diversity, differentiation and relationship among Indonesian indigenous chickens using molecular DNA markers.

\section{METHODOLOGY}

\section{Sample collection and DNA extraction}

A total of 1178 samples were collected from 49 populations of 14 most popular indigenous chicken breeds located in different parts of Indonesia. Geographic locations for sampling were chosen following specific administrative boundaries, Table 1. Sampling of related individuals was avoided using the information given by farmers.

Table 1. Details of the samples

\begin{tabular}{llll}
\hline Breeds & Population & Sampling location of the populations & $\begin{array}{l}\text { No. of } \\
\text { samples }\end{array}$ \\
\hline Kampung & AC & Naggroe Aceh Darussalam, North & 34 \\
& Sumatera & 28 \\
& SUA & North Sumatera & 26 \\
& SUB & North Sumatera & 19 \\
SUC & North Sumatera & 48 \\
SUD & North Sumatera & 28 \\
LAMA & Lampung, South Sumatra & 35 \\
LAMB & Lampung, South Sumatra & 34 \\
LAMC & Lampung, South Sumatra & 20 \\
BANA & Serang, Banten, West Java & 28 \\
BANB & Serang, Banten, West Java & 18 \\
BANC & Serang, Banten, West Java & 17 \\
BAND & Serang, Banten, West Java & 10 \\
BANE & Serang, Banten, West Java & 16 \\
\hline BANF & Serang, Banten, West Java & \\
\hline
\end{tabular}




\begin{tabular}{|c|c|c|c|}
\hline & MANA & Manado, North Sulawesi & 21 \\
\hline & MANB & Manado, North Sulawesi & 21 \\
\hline & MANC & Manado, North Sulawesi & 13 \\
\hline & MAND & Manado, North Sulawesi & 32 \\
\hline & MANE & Manado, North Sulawesi & 38 \\
\hline & MANF & Manado, North Sulawesi & 15 \\
\hline & MANG & Manado, North Sulawesi & 32 \\
\hline & MANH & Manado, North Sulawesi & 16 \\
\hline & MANI & Manado, North Sulawesi & 15 \\
\hline & MANJ & Manado, North Sulawesi & 30 \\
\hline & LOM & Lombok & 45 \\
\hline & MALA & Maluku & 20 \\
\hline & MALB & Maluku & 20 \\
\hline & MALC & Maluku & 10 \\
\hline & POSA & Poso, Central Sulawesi & 26 \\
\hline & POSB & Poso, Central Sulawesi & 24 \\
\hline Merawang & MR & BPTU Ayam, Sembawa, South Sumatera & 30 \\
\hline Pelung & PL & BPTU Ayam, Sembawa, South Sumatera & 14 \\
\hline & PLC & Cianjur, West Java & 30 \\
\hline Wareng & Tang & Tangerang, West Java & 19 \\
\hline Kedu Putih & KdPJ & Jatiwangi, West Java & 9 \\
\hline (white) & $\mathrm{KdP}$ & Kedu, Temanggung, Central Java & 18 \\
\hline Kedu & $\mathrm{Kd}$ & Kedu, Temanggung, Central Java & 29 \\
\hline & $\mathrm{KdH}$ & Kedu, Temanggung, Central Java & 14 \\
\hline Sentul & STC & Ciamis, West Java & 17 \\
\hline & STJ & Jatiwangi, West Java & 31 \\
\hline Kapas & KPS & Kedu, Temanggung, Central Java & 30 \\
\hline Kate & KT & Yogyakarta, Central Java & 32 \\
\hline Cemani & $\mathrm{CM}$ & Kedu, Temanggung, Central Java & 35 \\
\hline Gaok & GA & Bangkalan, Madura Island & 10 \\
\hline Tolaki & KTO & Konawe, South East Sulawesi & 20 \\
\hline Kalosi & KAL & Gowa, South Sulawesi & 30 \\
\hline Nunukan & Nunu & Nunukan and Sebatik, East Kalimantan & 25 \\
\hline & NT & Tarakan, East Kalimantan & 30 \\
\hline
\end{tabular}

Genomic DNA was extracted from whole blood according to the phenol-chloroform method described by Green and Sambrook (2012). The samples were genotyped using 20 autosomal microsatellite loci (Table 2) that have been recommended by the International Society for Animal Genetics (ISAG)/Food and Agriculture Organization (FAO) of the United Nations Advisory Committee on measurement of domestic animal genetic diversity (FAO, 2011). 
Table 2. Information of 20 microsatellite DNA markers for PCR amplification

\begin{tabular}{|c|c|c|c|c|}
\hline Primer & Forward primer (5'-3') & Reverse primer (5'-3') & Size (bp) & $\operatorname{Tm}\left({ }^{\circ} \mathbf{C}\right)^{*}$ \\
\hline ADL0268 & CTCCACCСCTCTCAGAACTA & CAACTTCCCATCTACCTACT & $102-106$ & 60 \\
\hline ADL0278 & CCAGCAGTCTACCTTCCTAT & TGTCATCCAAGAACAGTGTG & $114-126$ & 60 \\
\hline LEI0094 & GATCTCACCAGTATGAGCTGC & TCTCACACTGTAACACAGTGC & $247-287$ & 58 \\
\hline MCW0216 & GGGTTTTACAGGATGGGACG & AGTTTCACTCCCAGGGCTCG & 139-149 & 60 \\
\hline MCW0248 & GTTGTTCAAAAGAAGATGCATG & TTGCATTAACTGGGCACTTTC & $205-225$ & 61 \\
\hline MCW0034 & TGCACGCACTTACATACTTAGAGA & TGTCCTTCCAATTACATTCATGGG & $212-246$ & 59 \\
\hline MCW0069 & GCACTCGAGAAAACTTCCTGCG & ATTGCTTCAGCAAGCATGGGAGGA & $158-176$ & 58 \\
\hline MCW0081 & GTTGCTGAGAGCCTGGTGCAG & CCTGTATGTGGAATTACTTCTC & $112-135$ & 58 \\
\hline MCW0222 & GCAGTTACATTGAAATGATTCC & TTCTCAAAACACCTAGAAGAC & $220-226$ & 62 \\
\hline MCW0295 & ATCACTACAGAACACCCTCTC & TATGTATGCACGCAGATATCC & $88-106$ & 60 \\
\hline LEI0166 & CTCCTGCCCTTAGCTACGCA & TATCCCCTGGCTGGGAGTTT & $354-370$ & 58 \\
\hline LEI0234 & ATGCATCAGATTGGTATTCAA & CGTGGCTGTGAACAAATATG & $216-364$ & 59 \\
\hline MCW0037 & ACCGGTGCCATCAATTACCTATTA & GAAAGCTCACATGACACTGCGAAA & $154-160$ & 55 \\
\hline MCW0111 & GCTCCATGTGAAGTGGTTTA & ATGTCCACTTGTCAATGATG & $96-120$ & 57 \\
\hline MCW0016 & ATGGCGCAGAAGGCAAAGCGATAT & TGGCTTCTGAAGCAGTTGCTATGG & $162-206$ & 62 \\
\hline MCW0206 & ACATCTAGAATTGACTGTTCAC & CTTGACAGTGATGCATTAAATG & $221-249$ & 60 \\
\hline MCW0014 & TATTGGCTCTAGGAACTGTC & GAAATGAAGGTAAGACTAGC & $164-182$ & 58 \\
\hline MCW0067 & GCACTACTGTGTGCTGCAGTTT & GAGATGTAGTTGCCACATTCCGAC & $176-186$ & 60 \\
\hline MCW0183 & ATCCCAGTGTCGAGTATCCGA & TGAGATTTACTGGAGCCTGCC & $296-326$ & 58 \\
\hline MCW0330 & TGGACCTCATCAGTCTGACAG & AATGTTCTCATAGAGTTCCTGC & $256-300$ & 60 \\
\hline
\end{tabular}

*Tm - annealing temperature for each of the primer pairs 


\section{Microsatellite DNA amplification and genotyping}

Approximately 10-100 ng of genomic DNA were used in the amplification reaction. In a total $12 \mu \mathrm{L}$ reaction typically contained $1.5 \mu \mathrm{L}$ of extracted DNA, distilled water, buffer, dNTPs, $\mathrm{MgCl}_{2}$, Taq DNA polymerase and primers. All amplifications were carried out on Applied Biosystems 9700 Thermal Cycler Gene Amp ${ }^{\circledR}$ and involved an initial denaturation at $94^{\circ} \mathrm{C}$ for $5 \mathrm{~min}, 30$ cycles of denaturation at $94^{\circ} \mathrm{C}$ for $30 \mathrm{~s}$, primer annealing at temperatures varying between $55^{\circ} \mathrm{C}$ and $62^{\circ} \mathrm{C}$ depending on primer compositions (Table 2) for $1 \mathrm{~min}$, and extension at $72^{\circ} \mathrm{C}$ for $30 \mathrm{~s}$. A final extension step at $72^{\circ} \mathrm{C}$ for $7 \mathrm{~min}$ completed the polymerase chain reaction (PCR). Genotyping was carried out on a Genetic Analyzer $3130 \mathrm{xl}$ (Applied Biosystems) using internal size standard Gene Scan-500 LIZ ${ }^{\mathrm{TM}}$. Allele size calling and binning were carried out using program GeneMapper version 3.7 (Applied Biosystems).

\section{Data analysis}

Allelic diversity (i.e. total number of alleles, mean number of alleles (MNA) and genetic diversity (i.e. observed $\left(\mathrm{H}_{\mathrm{O}}\right)$ and expected $\left(\mathrm{H}_{\mathrm{E}}\right)$ heterozygosity) were calculated using program Microsatellite Toolkit (Park, 2001). Within-population genetic variation $\left(\mathrm{F}_{\mathrm{IS}}\right)$, an indicator of the level of genetic inbreeding of a population, was estimated following Weir and Cockerham (1984) using program FSTAT version 2.9.3.2 (Goudet, 1995, 2002). The significant level of $F_{I S}$ values was tested for 19,600 randomisations not assuming HardyWeinberg equilibrium. Phylogenetic relationships among populations were constructed based on the Nei's (1972) standard genetic distances (Ds) for allelic frequency data using program PHYLIP version 3.69 (Felsenstein, 1989, 2005). The confidence in each node was assessed by bootstrapping at 1000 replicates. The un-rooted consensus neighbour-joining phylogenetic tree was visualized using program TreeView version 1.6.6 (Page, 1996).

\section{RESULTS AND DISCUSSION}

Up to 259 alleles were observed for these 49 populations of 14 major Indonesian indigenous chicken breeds across 20 loci. The MNA per locus, $\mathrm{H}_{\mathrm{O}}$ and $\mathrm{H}_{\mathrm{E}}$ per population are presented in Table 3. The MNA per locus ranged from 4.20 in PL to 7.60 in SUD. The $\mathrm{H}_{\mathrm{O}}$ and $\mathrm{H}_{\mathrm{E}}$ values averaged over loci showed an overall distribution pattern similar to that observed for MNA per locus. $\mathrm{H}_{\mathrm{O}}$ varied from 0.50 in NT to 0.67 in BANC and $\mathrm{H}_{\mathrm{E}}$ from 0.55 in KPS to 0.72 in SUA. The observed within-population diversity measures indicated that Indonesian indigenous chicken populations were not only rich in genetic diversity but also highly differentiated from each other; therefore most of these indigenous chickens were warranted to develop specific utilization and conservation programs. In contrast, Spanish native chicken breeds, opposite to what was observed in present study, had low MNA values and they were already maintained in conservation program (Dávila et al., 2009). The high number of observed alleles in Indonesian indigenous chicken populations might be attributed to their large effective ancestral population sizes and continuous gene flow among different chicken populations. This could be possible as village chickens are raised normally in free range system, mixing with other chicken flocks. Similar results were also observed in freeranging African chickens (Zimbabwean, Malawian and Sudanese) (Muchadeyi et al., 2007).

A synthetic map constructed based on interpolated MNA values in Indonesian indigenous chicken populations using the Kriging gridding method showed gradient lines of influences from outside the country through different directions (Figure 1A). The areas with blue colour 
in most part of Java Island and middle part of Sumatera Island represented a relatively low number of alleles, indicating that indigenous chickens around these areas had low genetic diversity. On the other hand, the red colour in North Sumatera, South Sumatera, West Java and North Sulawesi showed a high number of alleles, revealing high diversity of indigenous chickens in these areas. The high diversity in those areas might be attributed to historical migrations of human populations and to trade. Being the centre for trading, Indonesian indigenous chicken could have had high opportunity in mixing with exotic chicken carried by traders. The high diversity observed in South Sumatera and West Java might be due to the influence of commercial chickens as in these areas indigenous chickens and commercial chickens were reared together. However, this is not true for North Sumatera where the high diversity might be due to historical admixtures. North Sulawesi areas also hosted important ports around Makassar Strait. These areas have attracted name for spice trading with the Portuguese since 1525, and could have been connected by trade with the cities around the strait, such as Manado, Maluku, or even the Philippines. The high diversity around these areas may thus have probably been influenced from the Philippines because northern part of these areas lies on the international route to the Pacific.

Synthetic maps of $\mathrm{H}_{\mathrm{O}}$ and $\mathrm{H}_{\mathrm{E}}$ estimates (Figures $1 \mathrm{~B}$ and 1C) showed slightly different patterns compared with that of MNA (Figure 1A). The influence of Malacca Strait and Makassar Strait can still be found in present indigenous chicken populations found along the trade routes. However, a slight difference was observed in terms of a relatively high MNA in the south part extending into the middle of Sumatera., Middle Java also showed an increased $\mathrm{H}_{\mathrm{E}}$.

The distribution pattern of $\mathrm{F}_{\mathrm{IS}}$ estimates showed the opposite trend to those shown by to those of MNA, $\mathrm{H}_{\mathrm{O}}$ and $\mathrm{H}_{\mathrm{E}}$. Except the BANE population with a very marginal negative value $(-0.002, P>0.05)$, all remaining $\mathrm{F}_{\mathrm{IS}}$ values were positive, suggesting that inbreeding was common in almost all Indonesian indigenous chicken populations, of which 32 reached significant levels $(P<0.05)$, suggesting a need for genetic intervention; for examples, exchange of breeding cocks among flocks to avoid the possible negative impact of inbreeding depression on survival, reproduction and productivity. The areas with red colour (Aceh, Yogyakarta, Nunukan, and Sebatik) showed the highest values of $\mathrm{F}_{\text {IS }}$ which indicate a high risk due to inbreeding within the relevant populations whereas areas with blue colour indicate the absence of risk of inbreeding (Figure 1D). High levels of inbreeding might be associated with historical isolations of some of the indigenous chicken populations. It is interesting to note a significantly high $\mathrm{F}_{\mathrm{IS}}$ value $(P<0.001)$ in the Kampung chicken population (AC) sampled in Naggroe Aceh Darussalam province. Aceh, is lying in the gate of Malacca Strait in North Sumatera and was the most wealthy, powerful and cultivated state in the Malacca Strait area in early 17th century. Although high MNA and $\mathrm{H}_{\mathrm{E}}$ values were observed in relevant chicken populations due probably to historical introduction of exotic chickens into this area, the geographic isolations from other parts of Indonesia and also outside world in recent centuries could have led to the accumulation of inbreeding within these chicken populations in the recent past. 
Table 3. Indicators of genetic diversity and $F$-statistics in 49 Indonesian indigenous chicken populations analyzed using 20 microsatellite markers

\begin{tabular}{|c|c|c|c|c|}
\hline Population & $H_{0} \pm \mathrm{SD}$ & $H_{\mathrm{E}} \pm \mathrm{SD}$ & MNA \pm SD & $F_{\text {IS }}$ \\
\hline $\mathrm{AC}$ & $0.62 \pm 0.02$ & $0.71 \pm 0.03$ & $7.50 \pm 3.14$ & $0.134 * * *$ \\
\hline SUA & $0.65 \pm 0.02$ & $\mathbf{0 . 7 2} \pm 0.03$ & $7.45 \pm 2.14$ & $0.099 * * *$ \\
\hline SUB & $0.58 \pm 0.02$ & $0.66 \pm 0.03$ & $6.30 \pm 1.78$ & $0.124 * * *$ \\
\hline SUC & $0.65 \pm 0.02$ & $0.66 \pm 0.03$ & $5.65 \pm 2.11$ & 0.013 \\
\hline SUD & $0.64 \pm 0.02$ & $0.69 \pm 0.03$ & $\mathbf{7 . 6 0} \pm 3.23$ & $0.063 * * *$ \\
\hline LAMA & $0.59 \pm 0.02$ & $0.69 \pm 0.03$ & $7.00 \pm 2.38$ & $0.156 * * *$ \\
\hline LAMB & $0.66 \pm 0.02$ & $0.69 \pm 0.03$ & $6.80 \pm 2.26$ & $0.045^{*}$ \\
\hline LAMC & $0.63 \pm 0.02$ & $0.68 \pm 0.03$ & $7.30 \pm 2.25$ & $0.074 * * *$ \\
\hline BANA & $0.61 \pm 0.02$ & $0.67 \pm 0.03$ & $5.75 \pm 1.83$ & $0.096 * * *$ \\
\hline BANB & $0.58 \pm 0.03$ & $0.68 \pm 0.03$ & $5.75 \pm 2.00$ & $0.148 * * *$ \\
\hline BANC & $\mathbf{0 . 6 7} \pm 0.02$ & $0.71 \pm 0.02$ & $6.30 \pm 1.75$ & $0.060 * *$ \\
\hline BAND & $0.64 \pm 0.03$ & $0.70 \pm 0.03$ & $6.60 \pm 2.21$ & $0.091 * * *$ \\
\hline BANE & $0.59 \pm 0.03$ & $0.59 \pm 0.03$ & $4.40 \pm 1.14$ & -0.002 \\
\hline BANF & $0.65 \pm 0.03$ & $0.67 \pm 0.03$ & $5.10 \pm 1.71$ & 0.036 \\
\hline JWT & $0.61 \pm 0.03$ & $0.70 \pm 0.02$ & $5.75 \pm 1.74$ & $0.136 * * *$ \\
\hline MANA & $0.58 \pm 0.02$ & $0.65 \pm 0.04$ & $5.85 \pm 2.30$ & $0.100 * * *$ \\
\hline MANB & $0.58 \pm 0.02$ & $0.68 \pm 0.03$ & $6.45 \pm 2.52$ & $0.153 * * *$ \\
\hline MANC & $0.60 \pm 0.03$ & $0.66 \pm 0.04$ & $5.75 \pm 2.05$ & $0.094 * *$ \\
\hline MAND & $0.60 \pm 0.02$ & $0.66 \pm 0.03$ & $6.40 \pm 2.56$ & $0.096 * * *$ \\
\hline MANE & $0.64 \pm 0.02$ & $0.71 \pm 0.02$ & $7.25 \pm 2.95$ & $0.094 * * *$ \\
\hline MANF & $0.59 \pm 0.03$ & $0.65 \pm 0.04$ & $5.85 \pm 2.70$ & $0.098 * *$ \\
\hline MANG & $0.66 \pm 0.02$ & $0.68 \pm 0.03$ & $7.25 \pm 2.77$ & 0.028 \\
\hline MANH & $0.60 \pm 0.03$ & $0.68 \pm 0.03$ & $5.35 \pm 1.81$ & $0.127 * * *$ \\
\hline MANI & $0.62 \pm 0.03$ & $0.67 \pm 0.03$ & $6.05 \pm 2.31$ & $0.078 * *$ \\
\hline MANJ & $0.63 \pm 0.02$ & $0.70 \pm 0.03$ & $6.50 \pm 2.56$ & $0.097 * * *$ \\
\hline LOM & $0.58 \pm 0.02$ & $0.65 \pm 0.04$ & $7.55 \pm 3.07$ & $0.109 * * *$ \\
\hline MALA & $0.65 \pm 0.02$ & $0.67 \pm 0.03$ & $6.25 \pm 2.36$ & 0.032 \\
\hline MALB & $0.62 \pm 0.02$ & $0.69 \pm 0.02$ & $6.35 \pm 2.11$ & $0.109 * * *$ \\
\hline MALC & $0.63 \pm 0.03$ & $0.66 \pm 0.03$ & $5.25 \pm 2.51$ & 0.055 \\
\hline POSA & $0.60 \pm 0.02$ & $0.66 \pm 0.03$ & $6.25 \pm 2.27$ & $0.090 * * *$ \\
\hline POSB & $0.60 \pm 0.02$ & $0.66 \pm 0.03$ & $6.05 \pm 1.88$ & $0.099 * * *$ \\
\hline MR & $0.62 \pm 0.02$ & $0.68 \pm 0.03$ & $5.85 \pm 2.25$ & $0.082 * * *$ \\
\hline PL & $0.59 \pm 0.03$ & $0.64 \pm 0.03$ & $\mathbf{4 . 2 0} \pm 1.06$ & $0.071^{*}$ \\
\hline PLC & $0.61 \pm 0.02$ & $0.62 \pm 0.02$ & $5.75 \pm 1.59$ & 0.007 \\
\hline Tang & $0.57 \pm 0.03$ & $0.60 \pm 0.04$ & $4.50 \pm 1.57$ & 0.048 \\
\hline KdPJ & $0.66 \pm 0.04$ & $0.68 \pm 0.03$ & $4.45 \pm 1.57$ & 0.041 \\
\hline KdP & $0.63 \pm 0.03$ & $0.65 \pm 0.03$ & $5.25 \pm 1.94$ & 0.024 \\
\hline $\mathrm{Kd}$ & $0.65 \pm 0.02$ & $0.68 \pm 0.03$ & $6.20 \pm 2.19$ & 0.039 \\
\hline $\mathrm{KdH}$ & $0.65 \pm 0.03$ & $0.68 \pm 0.03$ & $5.30 \pm 1.87$ & 0.033 \\
\hline STC & $0.56 \pm 0.03$ & $0.67 \pm 0.03$ & $5.35 \pm 1.50$ & $0.157 * * *$ \\
\hline STJ & $0.66 \pm 0.02$ & $0.69 \pm 0.02$ & $6.40 \pm 2.41$ & 0.037 \\
\hline KPS & $0.54 \pm 0.02$ & $\mathbf{0 . 5 5} \pm 0.04$ & $4.25 \pm 1.65$ & 0.026 \\
\hline KT & $0.53 \pm 0.02$ & $0.66 \pm 0.03$ & $5.15 \pm 1.27$ & $0.196 * * *$ \\
\hline $\mathrm{CM}$ & $0.59 \pm 0.02$ & $0.66 \pm 0.03$ & $6.35 \pm 1.93$ & $0.121 * * *$ \\
\hline GA & $0.60 \pm 0.04$ & $0.63 \pm 0.05$ & $4.50 \pm 1.99$ & 0.052 \\
\hline KTO & $0.66 \pm 0.02$ & $0.67 \pm 0.04$ & $6.25 \pm 2.20$ & 0.020 \\
\hline KAL & $0.63 \pm 0.02$ & $0.67 \pm 0.03$ & $6.25 \pm 2.10$ & $0.061 * *$ \\
\hline Nunu & $0.60 \pm 0.02$ & $0.64 \pm 0.04$ & $5.40 \pm 1.76$ & $0.059 *$ \\
\hline NT & $\mathbf{0 . 5 0} \pm 0.02$ & $0.61 \pm 0.03$ & $5.85 \pm 1.60$ & $0.183 * * *$ \\
\hline
\end{tabular}

* for $P<0.05, * * P<0.01$ and $* * * P<0.001$ based on 19,600 randomisations not assuming HardyWeinberg equilibrium. The extreme values in each column are highlighted in bold fonts. 

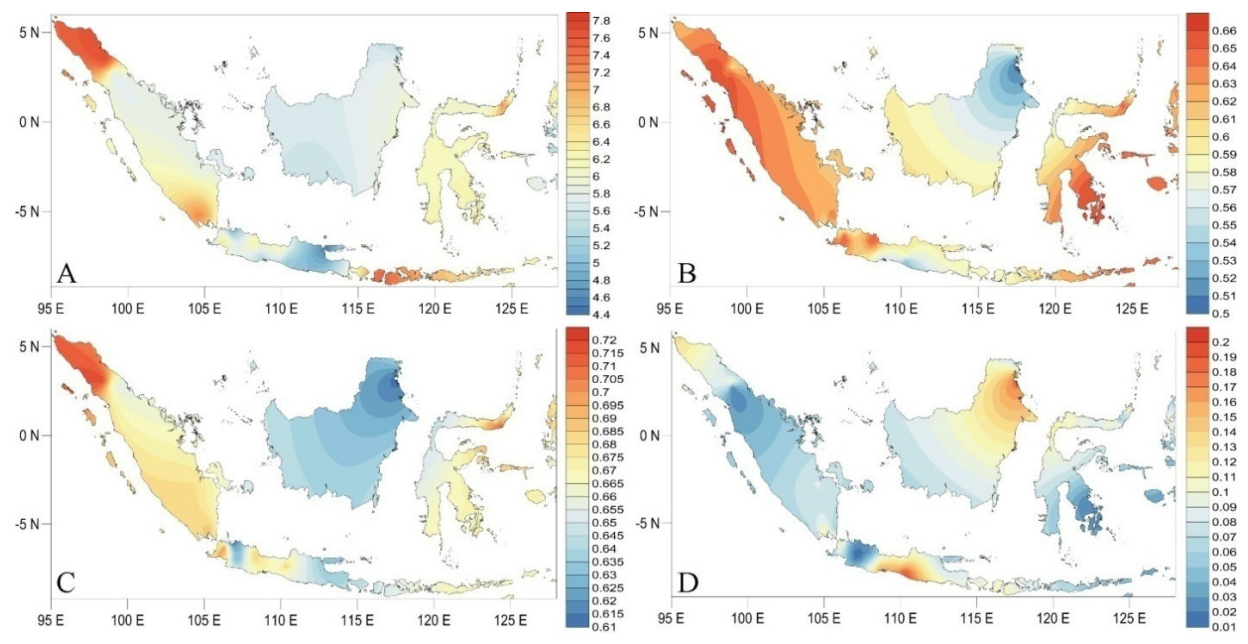

Fig. 1. Synthetic maps illustrating geographic variation of the Indonesian indigenous chickens using MNA (A), $H_{O}(\mathrm{~B}), H_{\mathrm{E}}(\mathrm{C})$ and $\boldsymbol{F}_{\mathrm{IS}}(\mathrm{D})$ estimates

A phylogenetic tree showing the relationships among 49 Indonesian indigenous chicken populations based on Nei's Ds estimates is presented in Figure 2. In general, there is no clear clustering pattern among the Indonesian indigenous chicken populations except for KDH, $\mathrm{KdP}$ and KD from Central Java together with KdPJ, STJ and Tang from West Java forming a separate cluster while MANA from North Sulawesi and MR from South Sumatra also joining the same cluster. Based on the information on morphology and management practice of these chicken populations, separation of this cluster could be attributed to the certain level of crossbreeding of indigenous chickens with exotic commercial breeds/lines. Another small cluster including NT and Nunu, (Figure 2) from East Kalimantan, was probably explained by their relatively isolated distribution from other Indonesian chicken populations and closed breeding within the area over historical times.

This study presents the results of nearly complete sampling done for genetic characterization of Indonesian indigenous chicken populations for the first time. Our results validated the observation of Riztyan et al., (2011) on a close relationship between undetermined Kedu and Kampung chickens. Ahigh within population genetic diversity but rather limited genetic differentiation among Indonesian indigenous chicken populations detected at autosomal microsatellite loci were also observed in most of the unselected, nondescript indigenous chicken populations in Asia and Africa due probably to their common and recent origin, large effective population size and frequent gene flow (Msoffe et al., 2005; Muchadeyi et al., 2007; Mwacharo et al., 2007; Osei-Amponsah et al., 2010; Mtileni et al., 2011; Berima et al., 2013). However, the genetic introgression of commercial chicken breeds/lines into KDH, KdP and KD from Central Java, KdPJ, STJ and Tang from West Java, MANA from North Sulawesi and MR from South Sumatra, though limited in its impact, did shape the genetic structure of these populations related to long-term improvement programs, such as the distribution of crossbred chicks with commercial genetic background to local householders (Leroy et al., 2012). On the other hand, a rather clear genetic distinction was observed among most of the well-established European, Chinese, Japanese and Korean indigenous and commercial chicken breeds and lines following historical extensive and recent intensive selection for specific phenotypes and/or high productivity (Romanov and Weigend, 2001; 
Tadano et al., 2007a, 2007b, 2008; Bodzsar et al., 2009; Ding et al., 2010; Zanetti et al., 2010; Seo et al., 2013). Nevertheless, local chickens in Africa, Asia and South America were found to be genetically distinctive (Wimmers et al., 2000) due to their ancient and large geographic isolations. Most of the Indonesian indigenous chicken breeds/populations were also highly diversified because of their isolated distribution in different islands and also because of their historical interaction with other chicken genetic resources through regional trading in the past. Hence, they are warranted for conservation through sustainable utilization programs.

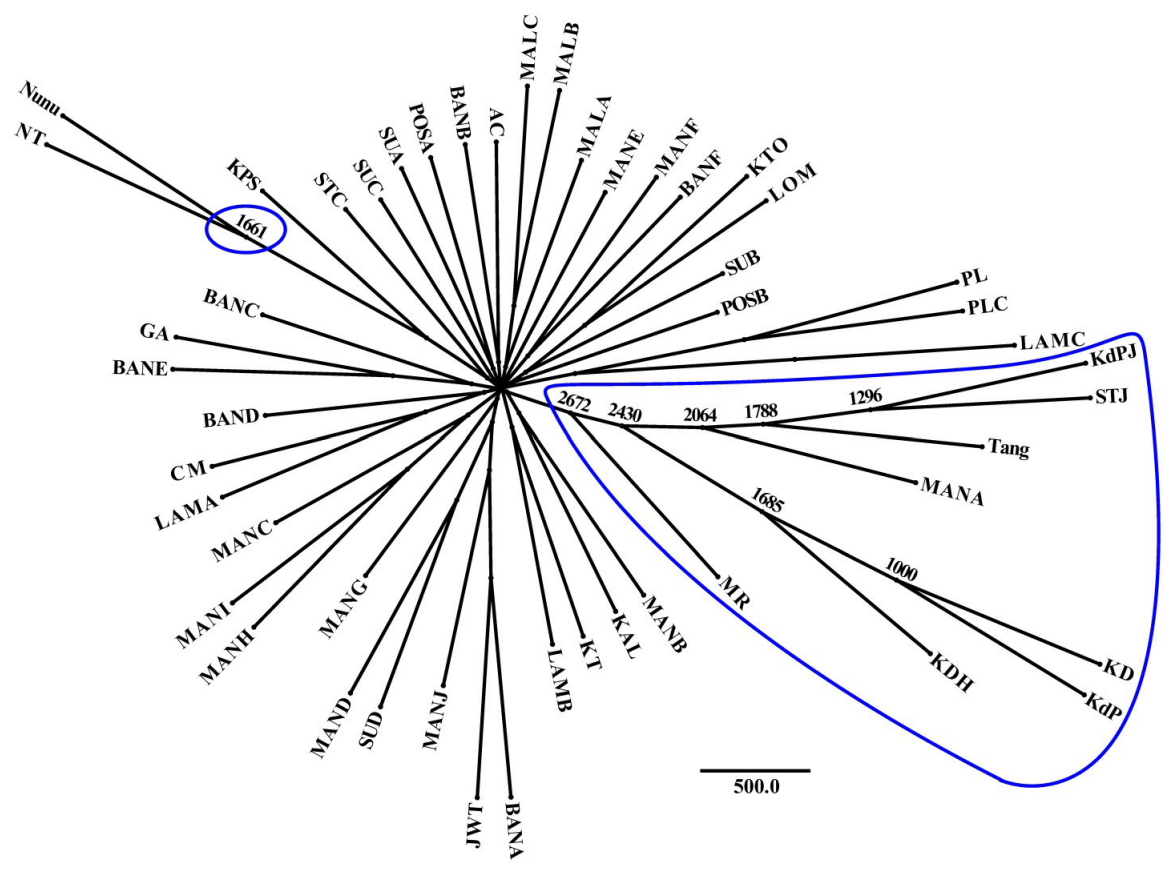

Fig. 2. Phylogenetic tree among 49 Indonesian indigenous chicken populations based on Nei's $D$ s estimations

\section{CONCLUSIONS}

The molecular characterization of nearly complete sampling of 49 populations belonging to 14 major Indonesian indigenous chicken breeds genotyped for the first time using 20 autosomal microsatellite DNA markers indicated that there is rich and unique genetic diversity among most of the populations. The amount of genetic diversity is partitioned between major islands with most of them showing significant level of inbreeding within populations. Although the genetic differentiation among most of these populations across islands is not significant due to recent and frequent gene flow, most probably due introgression with commercial chicken breeds/lines especially in those population in urban areas , leading to different genetic structures. Some localized populations in certain islands have evolved into distinct genetic background due to historical trading and long term geographic isolation. These findings will help providing scientific basis for the development of rational policies supporting conservation and sustainable utilization efforts. 


\section{ACKNOWLEDGEMENTS}

Special thanks to all farmers for their cooperation during field sampling. We appreciated Zeng Shengcheng, E Guangxing and Neena Amatya Gorkhali for their assistance during lab work and data analysis. H. Ashari was granted a Chinese government scholarship. This study was supported by the funding to CAAS-ILRI joint laboratory from CAAS.

\section{REFERENCES}

Berima, M.A., Yousif, I.A., Eding, H., Weigend, S. and Musa, H.H. (2013). Population structure and genetic diversity of Sudanese native chickens. Afr. J. Biotech., 12, 6424 - 6431.

Bodzsar, N., Eding, H., Revay, T., Hidas, A. and Weigend, S. (2009). Genetic diversity of Hungarian indigenous chicken breeds based on microsatellite markers. Anim. Genet., 40, $516-523$.

Crawford, R.D. (1990). Poultry Breeding and Genetics. Elsevier Science Publisher B.V., Netherlands.

Dávila S.G., Gil M.G., Resino-Talaván P. and Campo J.L. (2009). Evaluation of diversity between different Spanish chicken breeds, a tester line, and White Leghorn population based on microsatellite markers. Poult. Sci., 88, 2518 - 2525.

Ding, F.X., Zhang, G.X., Wang, J.Y., Li, Y., Zhang, L.J., Wei, Y., Wang, H.H., Zhang, L. and Hou, Q.R. (2010). Genetic diversity of a Chinese native chicken breed, Bian chicken, based on twenty-nine microsatellite markers. Asian-Aust. J. Anim. Sci., 23, 154 - 161.

FAO. (2011). Molecular Genetic Characterization of Animal Genetic Resources. FAO Animal Production and Health Guidelines. No. 9. Rome, Italy.

Felsenstein, J. (1989). PHYLIP - Phylogeny Inference Package (version 3.2). Cladistics, 5, $164-166$.

Felsenstein, J. (2005). PHYLIP - Phylogeny Inference Package (version 3.6). Distributed by the author. Department of Genome Sciences, University of Washington, Seattle, USA.

Fumihito, A., Miyake, T., Sumi, S., Takada, M., Ohno, S. and Kondo, N. (1994). One subspecies of the red jungle fowl (Gallus gallus gallus) suffices as the matriarchic ancestor of all domestic breeds. Proc. Natl. Acad. Sci. USA., 91, 12505 - 12509.

Fumihito, A., Miyake, T., Takada, M., Shingu, R., Endo, T.,Gojobori, T., Kondo, N. and Ohno, S. (1996). Monophyletic origin and unique dispersal patterns of domestic fowls. Proc. Natl. Acad. Sci. USA., 93, 6792 - 6795.

Goudet, J. (1995). FSTAT (Version 1.2): A computer program to calculate F-statistics. J. Hered., 86, 485 - 486. 
Goudet, J. (2002). FSTAT, a program to estimate and test gene diversities and fixation indices (version 2.9.3.2). Available at http://www.unil.ch/izea/softwares/fstat.html.

Green, M.R. and Sambrook, J. (2012). Molecular Cloning: A Laboratory Manual (4th edition). Cold Spring Harbor Laboratory Press, New York, USA.

Hillel, J., Groenen, M.A., Tixier-Boichard, M., Korol, A.B., David, L., Kirzhner, V.M., Burke, T., Barre-Dirie, A., Crooijmans, R.P., Elo, K., Feldman, M.W., Freidlin, P.J., MakiTanila, A., Oortwijn, M., Thomson, P., Vignal, A., Wimmers, K. and Weigend, S. (2003). Biodiversity of 52 chickens populations assessed by microsatellite typing of DNA pools. Genet. Sel. Evol., 2003, 35, 533 - 557.

Leroy, G., Kayang, B.B., Youssao, I.A., Yapi-Gnaoré, C.V, Osei-Amponsah, R., Loukou, N.E., Fotsa, J.C., Benabdeljelil, K., Bed'hom, B., Tixier-Boichard, M. and Rognon, X. (2012). Gene diversity, agroecological structure and introgression patterns among village chicken populations across North, West and Central Africa. BMC Genetics, 13, 34.

Lindqvist, C.E.S., Schütz, K.E. and Jensen, P. (2002). Red jungle fowl have more contrafreeloading than White Leghorn layers: Effect of food deprivation and consequences for information gain. Behaviour, 139, 1195 - 1209.

Moiseyeva, I.G., Romanov, M.N., Sevastyanova, A.A. and Semyenova, S.K. (2003). Evolutionary relationships of red jungle fowl and chicken breeds. Genet. Sel. Evol., 35, 403 423.

Moreng, R. and Avens, J.S. (1985). Classification, nomenclature, and showing of poultry. In: Poultry Science and Production (Eds. Moreng R.E. and Avens J.S.). Reston Publishing Co., Inc. Prentice-Hall Company, Reston, Virginia 22090, USA. pp: 16-45.

Msoffe, P.L.M., Mtambo, M.M.A., Minga, U.M., Juul-Madsen, H.R. and Gwakisa, P.S. (2005). Genetic structure among the local chicken ecotypes of Tanzania based on microsatellite DNA typing. Afr. J. Biotech., 4, 768 - 771.

Mtileni, B.J., Muchadeyi, F.C., Maiwashe, A., Groeneveld, E., Groeneveld, L.F., Dzama, K. and Weigend, S. (2011). Genetic diversity and conservation of South African indigenous chicken populations. J. Anim. Breed. Genet., 128, 209 - 218.

Muchadeyi, F.C., Eding, H., Wollny, C.B.A., Groeneveld, E., Makuza, S.M., Shamseldin, R., Simianer, H. and Weigend, S. (2007). Absence of population sub-structuring in Zimbabwe chicken ecotypes inferred using microsatellite analysis. Anim. Genet., 38, 332 - 339.

Mwacharo, J.M., Nomura, K., Hanada, H., Jianlin, H., Hanotte, O. and Amano, T. (2007). Genetic relationships among Kenyan and other East African indigenous chickens. Anim. Genet., 38, 485-90.

Nataamijaya, A.G. (2000). The native of chicken of Indonesia. Buletin Plasma Nutfah, 6(1). Balitbang Pertanian, Departemen Pertanian, Indonesia.

Nei, M. (1972). Genetic distance between populations. American Naturalist, 106, 283 - 292. 
Osei-Amponsah, R., Kayang, B.B., Naazie, A., Osei, Y.D., Youssao,.IA., Yapi-Gnaore, V.C., Tixier-Boichard, M. and Rognon, X. (2010). Genetic diversity of Forest and Savannah chicken populations of Ghana as estimated by microsatellite markers. Anim. Sci. J., 81, 297 303.

Page, R.D.M. (1996). TREEVIEW: an application to display phylogenetic trees on personal computers. Computer Applications in the Biosciences, 12, 357 - 358.

Park, S.D.E. (2001). Trypanotolerance in West African Cattle and the Population Genetic Effects of Selection. Ph.D. thesis. University of Dublin, Ireland.

Riztyan, Katano, T., Shimogiri, T., Kawabe, K. and Okamoto, S. (2011). Genetic diversity and population structure of Indonesian native chickens based on single nucleotide polymorphism markers. Poult. Sci., 90, 2471 - 2478.

Romanov, M.N. and Weigend, S. (2001). Analysis of genetic relationships between various populations of domestic and jungle fowl using microsatellite markers. Poult. Sci., 80, 1057 1063.

Sartika T. (2007). Pembibitan Dan Peningkatan Mutu Genetik Ayam Lokal. LIPI Press, Indonesia.

Seo, D.W., Hoque, M.R., Choi, N.R., Sultana, H., Park, H.B., Heo, K.N., Kang, B.S., Lim, H.T., Lee, S.H., Jo, C. and Lee, J.H. (2013). Discrimination of Korean native chicken lines using fifteen selected microsatellite markers. Asian-Australas J. Anim. Sci., 26, 316 - 322.

Siegel, P.B., Haberfeld, A., Mukherjee, T.K., Stallard, L.C., Marks, H.L., Anthony N.B. and Dunnington, E.A. (1992). Junglefowl - domestic fowl relationship: A use of DNA fingerprinting. World's Poult. Sci. J. 48, 147 - 155.

Sulandari, S., Zein, M.S.A, Paryanti, S. and Sartika, T. (2007). Taksonomi Dan Asal-usul Ayam Domestikasi. LIPI Press, Indonesia.

Sullivan, M.S. (1991). Flock structure in red junglefowl. Appl. Anim. Behav. Sci., 30, 381 386.

Tadano, R., Nishibori, M., Imamura, Y., Matsuzaki, M., Kinoshita, K., Mizutani, M., Namikawa, T. and Tsudzuki, M. (2008). High genetic divergence in miniature breeds of Japanese native chickens compared to Red Junglefowl, as revealed by microsatellite analysis. Anim. Genet., 39, 71 - 78.

Tadano, R., Nishibori, M., Nagasaka, N. and Tsudzuki, M. (2007a). Assessing genetic diversity and population structure for commercial chicken lines based on forty microsatellite analyses. Poult. Sci., 86, 2301 - 2308.

Tadano, R., Sekino, M., Nishibori, M. and Tsudzuki, M. (2007b). Microsatellite marker analysis for the genetic relationships among Japanese long-tailed chicken breeds. Poult. Sci., 86,460 - 469. 
Väisänen, J. and Jensen, P. (2003). Social versus exploration and foraging motivation in young red junglefowl (Gallus gallus) and White Leghorn layers. Appl. Anim. Behav. Sci., $84,139-158$.

Väisänen, J., Håkansson, J. and Jensen, P. (2005). Social interactions in Red Junglefowl (Gallus gallus) and White Leghorn layers in stable groups and after re-grouping. Brit. Poult. Sci., 46, 156 - 168 .

Väisänen, J. and Jensen, P. (2004). Responses of young red jungle fowl (Gallus gallus) and White Leghorn layers to familiar and unfamiliar social stimuli. Poult. Sci., 83, 335 - 343.

Weeks, C.A. and Nicol, C.J. (2006). Behavioural needs, priorities and preferences of laying hens. World's Poult. Sci. J., 62, 296 - 307.

Weir, B.S. and Cockerham, C.C. (1984). Estimating F-statistics for the analysis of population structure. Evolution, 38, 1358 - 1370.

Wimmers, K., Ponsuksili, S., Hardge, T., Valle-Zarate, A., Mathur, P.K. and Horst, P. (2000). Genetic distinctness of African, Asian and South American local chickens. Anim. Genet., 31, 159 - 165.

Zanetti, E., de Marchi, M., Dalvit, C. and Cassandro, M. (2010). Genetic characterization of local Italian breeds of chickens undergoing in situ conservation. Poult. Sci., 89, 420 - 427. 